\title{
PREVALENCE OF COLOUR BLINDNESS AMONG SCHOOL CHILDREN IN MANDYA DISTRICT, KARNATAKA
}

\author{
Poornima Basavaraj ${ }^{1}$, Manjula Thamabuswamy Ramamurthy², Prathibha Shiveshi ${ }^{3}$
}

${ }_{1}^{1}$ Senior Resident, Department of Ophthalmology, Mandya Institute of Medical Sciences, Mandya, Karnataka, India. 2Professor and HOD, Department of Ophthalmology, Mandya Institute of Medical Sciences, Mandya, Karnataka, India. ${ }_{3}^{3}$ Postgraduate Student, Department of Ophthalmology, Mandya Institute of Medical Sciences, Mandya, Karnataka, India.

\section{ABSTRACT}

\section{BACKGROUND}

Many people suffer from colour blindness but most of them remain undetected. Hence screening at the level of school going age leads to early detection and helps in guiding them in studies and professional choices. We wanted to find the prevalence of colour blindness in the age group of 11-15 years of school going children and to compare the prevalence rate between male and female students in Mandya district, Karnataka.

\section{MATERIALS AND METHODS}

A cross sectional observational study was done on 1571 students from four different schools of the same city to assess the prevalence of colour blindness. Students were examined with Ishihara Pseudoisochromatic Colour Plates 38th Edition. If the student was found to be colour blind, the student was further classified into different types of colour blindness. The data collected was then analysed to evaluate the prevalence of colour blindness, compare the prevalence between male and female students.

\section{RESULTS}

A total of 1571 students were evaluated from 4 different schools of the Mandya district among which 897 (57.09\%) were males and $674(42.90 \%)$ were female students who were in the age group between 11-15 years. The prevalence of colour blindness was found to be $1.4 \%$ (23 students out of 1571 students). Colour blindness was seen in $21(1.3 \%)$ male students and $2(0.1 \%)$ female students. Among the colour blind, $20(1.2 \%)$ were protanopes, $3(0.2 \%)$ were deuteranopes and none were tritanope. Males were affected more than female students.

\section{CONCLUSION}

Significant male population suffers from the congenital colour vision disorder. Those with congenital colour vision disorder should be properly examined early for colour vision disorder to rule out colour blindness in school children. Proper guidance can then be given to students about leaning pattern and even in finding an appropriate job/profession.

\section{KEY WORDS}

Colour Vision, Congenital Red Green Colour Defect, Mandya, Prevalence, School Group Children

HOW TO CITE THIS ARTICLE: Basavaraj P, Ramamurthy MT, Shiveshi P. Prevalence of colour blindness among school children in Mandya district, Karnataka. J. Evolution Med. Dent. Sci. 2019;8(12):879-881, DOI: 10.14260/jemds/2019/195

\section{BACKGROUND}

Colour vision is an ability to discriminate a wave length of light stimulus as a function of rods and cones. The description and appreciation of colours depend upon the ability of receptors in retina i.e. rods and cones. David Brewster introduced the term colour blindness, which will be formerly known as daltonism after John Dalton, who described in detail his own inability to distinguish red in 1978.(1)

The prevalence of congenital colour blindness is about $8 \%$ in males and $0.4 \%$ in females, results either from the alterations or absence in the absorption spectrum of photopigment.(2) The frequency of colour blindness vary among different ethnic populations across the world.

'Financial or Other Competing Interest': None.

Submission 19-11-2018, Peer Review 09-03-2019,

Acceptance 16-03-2019, Published 25-03-2019.

Corresponding Author:

Poornima Basavaraj,

\#304 B, Doctors Quarters,

Mandya Institute of Medical Sciences,

Mandya-571401,

Karnataka, India

E-mail: skandaravi31@gmail.com

DOI: $10.14260 /$ jemds $/ 2019 / 195$
A recent study from Eastern India has reported $8.73 \%$ of males and $1.69 \%$ of females as colour blind.(3)

Colour blindness does not mean he/she could not appreciate any colour except white and black. It again depends on the types of colour in which only the primary colours like red, green and blue are affected it can be a single colour defect or involving two primary colours. The tests which are used in screening are Ishihara test plate, Nagel anomaloscope test, Farnsworth-Munsell hundred hue test but except Ishihara test all other tests are time consuming and cannot be used for mass screening. (4)

Colour blindness is an inherited trait and is caused by an alteration in the gene that codes for the photopigment in cone cells. Cone cells are what allow us to have detailed and colour vision. In colour-blind individuals the photopigment functions differently and causes a different colour perception. The gene that codes for colour-blindness is located on the $\mathrm{X}$ chromosome and is recessive ( $\mathrm{X}$-linked recessive). Because of this it affects men much more commonly than women. Men have one $\mathrm{X}$ chromosome and get the condition when they have the gene. Women have two $\mathrm{X}$ chromosomes and require two of the genes to be colour blind, which is quite rare. Between $2 \%-6 \%$ of men are colour blind and $0.5 \%$ of women are colour blind. Women are typically carriers. 
Not only colour blindness can be congenital/hereditary, but it can be acquired as due to retinal or due to hereditary condition, colour blindness may occur due to acquired due to retinal disease or toxicity or systemic conditions. (5) $^{(5)}$

\section{Classification of Colour Vision Deficiency}

1. Protanomaly- Red weakness.

2. Deuteranomaly- Green weakness.

3. Tritanomaly- Blue weakness.

4. Protanopia- Red deficiency.

5. Deuteranopia- Green deficiency.

6. Tritanopia- Blue deficiency.

7. Achromatopia- Absolute colour blindness.

Hence the screening is must in general population as these are undetected by the patients.(6)

The main aim of study is to screen children for colour blindness and know its prevalence rate and give both students and parents about the details of disability and guide them in proper way for learning process.

\section{MATERIALS AND METHODS}

A cross sectional study was conducted in 4 different nearby school to hospital out of 14 schools, after obtaining the permission from B.E.O. of Mandya district, Karnataka. Study was initiated after obtaining approval from the institutional Ethics Committee, MIMS, Mandya. Which was conducted over a period of three months from May 2017 to July 2017.

After obtaining permission from school Principal study was conducted. Informed consent was taken from each student of 4 schools. In each school from grade 6 th to grade 10th all students were called according to the roll number in a class room where a complete examination of vision and detailed examination of eye like slit lamp and fundus examination to rule out other pathologies/ocular disease was done. Later name, age and sex of each students were noted down. For colour vision Ishihara's Type Test chart was used.

Test was carried out by making the students to sit in front of examiner by holding the test chart at a distance of $75 \mathrm{cms}$ from the student and student is made to close one eye and read the number in each plate till all 38 plates are read or traced the colour. And answers were noted done. And again, the other eye was closed, and test was repeated. Followed by which presence of colour blindness were noted and again the colour blindness was divided into protanopes and deuteranopes depending on the response.

\section{Inclusion Criteria}

1. Students from 11-15 years.

2. Students willing to participate in present study.

3. School which were near and easily accessible to hospital.

\section{Exclusion Criteria}

1. Students with ocular pathology.

2. Any history of medication for more than one month.

\section{Sampling Method}

Convenient sampling.

\section{Statistical Analysis}

Descriptive statistical analysis has been carried out in the present study Prevalence $=$ Number of all current cases of specific disease existing at a given point in time $\mathrm{x}$ $100 /$ Estimated population at the same point in time.

\section{RESULTS}

A total of 1571 students were evaluated from 4 different schools of the Mandya district out of total 14 schools among which 897 (57.09\%) were males and 674 (42.90\%) female students from grade $6^{\text {th }}$ to grade $10^{\text {th }}$ were screened between 11 to 15 years. The prevalence of colour blindness was found to be in 23(1.4\%) student out of 1571 students. Colour blindness was seen in $21(1.3 \%)$ male students and $2(0.1 \%)$ female student affected (Table-1). Among the colour blind 20 $(1.2 \%)$ were protanopes, $3(0.2 \%)$ were deuteranopes and none were tritanope. (Table-2) Males were affected more compared to female students. The prevalence of protanopes were seen in male students where as deuteranopes were seen in both male and female students.

\begin{tabular}{|c|c|c|c|}
\hline \multirow{2}{*}{ Colour Blind } & \multicolumn{2}{|c|}{ Gender } & \multirow{2}{*}{ Total } \\
\cline { 2 - 3 } & Male & Female & \\
\hline Affected & $21(1.3 \%)$ & $2(0.1 \%)$ & $23(1.4 \%)$ \\
\hline Not Affected & $876(55.7 \%)$ & $672(42.7 \%)$ & $\begin{array}{c}1548 \\
(98.53 \%)\end{array}$ \\
\hline Total & $\mathbf{8 9 7}$ & $\mathbf{6 7 4}$ & $\mathbf{1 5 7 1}$ \\
\hline
\end{tabular}

Table 1. Gender Wise Distribution of Colour Blindness

\begin{tabular}{|c|c|c|c|}
\hline Colour Blind & Protanopes & Deuteranopes & Total \\
\hline Affected & $20(1.2 \%)$ & $3(0.19 \%)$ & $23(1.4 \%)$ \\
\hline \multicolumn{2}{|c|}{ Table 2. Distribution of Protanopes and Deuteranopes } \\
\hline
\end{tabular}

\begin{tabular}{|c|c|c|c|c|c|}
\hline \multirow{2}{*}{$\begin{array}{c}\text { Colour } \\
\text { Blind }\end{array}$} & \multicolumn{2}{|c|}{ Protanopes } & \multicolumn{2}{|c|}{ Deuteranopes } & \multirow{2}{*}{ Total } \\
\cline { 2 - 5 } & Male & Female & Male & Female & \\
\hline $\begin{array}{c}\text { Number } \\
(\%)\end{array}$ & 20 & & 1 & 2 & 23 \\
$(1.2 \%)$ & 0 & $(0.06 \%)$ & $(0.12 \%)$ & $(1.4 \%)$ \\
\hline
\end{tabular}

Table 3. Gender Wise Distribution of Type of Blindness

\section{DISCUSSION}

Colour vision test using the Ishihara's chart helps in diagnosis of colour blindness in mass population and it is more reliable than any other test for a screening purpose. ${ }^{7-9}$ Previous studies have shown the reliability of test chart i.e., according to the test results of these studies the sensitivity of the test chart is of $96 \%$ and specificity of $98.5 \%{ }^{10,11}$ Hence most of the time Ishihara test plates have been used in mass screening or for the diagnosis of colour blindness.

A study among school children of Patiala city, India reported $3.85 \%$ males and $0.38 \%$ females to be colour blind. In this study the type of colour blindness in Ethiopian population, which found $4.2 \%$ of males and $0.2 \%$ of females to have various forms of colour blindness. Similar study in Jat Sikhs of Patiala city of India, reported an incidence of 3.83\% and $0.13 \%$ in males and females respectively. 12

Bansod was carried out in total of 595 students in Pune showed the prevalence rate of $2.02 \%$ and found to be more in male students than female students.

Another study conducted in a total of 2001 students were examined, in which 1050 male students and 951 females with mean age of $10.35( \pm 2.75)$ and $10.54( \pm 2.72)$ respectively. Among the total students examined, $2.1 \%$ had some form of colour vision defects. Of the male population, $3.9 \%$ had colour 
vision defects while none of the female was found with the deficiency. ${ }^{13}$

Previous studies done of school going children and the elder age group from 15-45 years showed the report of prevalence i.e., $8.48 \%$ and $4.9 \% .14,15$

Osuobeni conducted a study in which the children showed the prevalence rate of $2.9 \%$ of colour blindness. ${ }^{16}$

As there is no treatment for colour blindness. Special contact lenses can be used to help some people with colour blindness distinguish the difference between colours. Some careers require good colour perception like being a lab technician who needs to interpret tests results-based colour or an electrician who needs to tell the difference between different coloured wires. Because of this those with colour blindness may need to limit their career options. In children it is important to know of colour blindness so teachers can adjust their lessons to provide a better learning environment.

\section{CONCLUSION}

The prevalence of colour blindness was noted to be higher in males (i.e. 1.3\%) when compared to that in females (i.e. $0.1 \%$ ). which can be seen depending on the pattern of inheritance of colour blindness.

In many cases, student remains unaware about the colour blindness disability. It may cause difficulties in learning and choosing profession. Hence early screening for colour vision disorder and utilising new method of teaching or learning process can lead to a better life and better profession.

\section{ACKNOWLEDGEMENT}

We gratefully acknowledge Dr. Aarthi Rajamanickam, Junior resident in ophthalmology, Mandya Institute of Medical Sciences for her suggestions and for helping in reviewing of the article.

\section{REFERENCES}

[1] Park K. Park's Textbook of Preventive and Social Medicine. 19th edn. Jabalpur, India: Banarasidas Bhanot Publishers 2007: p. 57.

[2] Shah A, Hussain R, Fareed M, et al. Prevalence of RedGreen colour vision defects among Muslim males and females of Manipur, India. Iran J Public Health 2013;42(1):16-24.
[3] McClements M, Davies WI, Michaelides M, et al. Xlinked cone dystrophy and colour vision deficiency arising from a missense mutation in a hybrid L/M cone opsin gene. Vision Res 2013;80:41-50.

[4] Subha L, Ramyaa M, Rajarathinam MS. Prevalence of congenital colour blindness among under-graduate medical students. Int J Pharm Bio Sci 2015;6(4):11146.

[5] Newell FW. Ophthalmology - Principles and concepts. $8^{\text {th }}$ edn. St. Louis, Mosby Year Book Inc., 1996: p. 157.

[6] Benjamin WJ. Borisch's Clinical Refraction. $2^{\text {nd }}$ edn. Butterworth-Heinemann - Elsevier, 2006: p. 289-97.

[7] Dain SJ, Gray S, Tran L. Colourimetric analysis and performance assessment of the Hahn new pseudoisochromatic colour vision test. Colour Res Application 1997;23:69-77.

[8] Birch J. Efficiency of Ishihara test for identifying RedGreen colour deficiency. Ophthal Physiol Opt 1997;17(5):403-8.

[9] Pease PL, Allen J. A new test for screening colour vision: concurrent validity and utility. Am J Optom Physiol Opt 1988;65(9):729-38.

[10] Johnson DD. The Ishihara test: on the prevention of job discrimination. J Am Optom Assoc 1992;63(5):352-60.

[11] Weir R, Kirk R, Bidwell S, et al. Colour vision screening. A critical appraisal of the literature. New Zealand Health Technology Assessment Clearing House. Report 7. October 1998.

[12] Agarwal S, Bansod N. Prevalence of colour blindness in school children. International Journal of Science and Research (IJSR) 2014;3(4):175-7.

[13] Shrestha RK. Colour vision defects in school going children. J Nepal Med Assoc 2010;50(180):264-6.

[14] Gallo GP, Panza M, Viviani F, et al. Congenital dyschromatopsia and school achievement. Percept Mot Skills 1998;86(2):563-9.

[15] Modarres M, Mirsamadi M, Peyman GA. Prevalence of congenital colour deficiencies in secondary school students in Tehran. Int Ophthalmol 19961997;20(4):221-2.

[16] Osuobeni EP. Prevalence of congenital Red-Green colour vision defects in Arab boys from Riyadh, Saudi Arabia. Ophthalmic Epidemiol 1996;3(3):167-70. 